\title{
COSMIC STATE: THE FORMING AND DEVELOPMENT OF THE IDEA IN THE HISTORY OF THOUGHT
}

\begin{abstract}
The article considers the philosophical-legal issues when forming and developing the idea about the cosmic state made by thinkers during different periods of time, starting from the Ancient World till Russian cosmism in the 20th century. It includes interpretations of ideas about the cosmic state in ancient mythology, in works of such thinkers as Antisfen, Diogenes of Sinope, Krates, Zeno, Platon, Iambulos, Seneca, Cicero, Dante, Augustine of Hippo, Thomas Paine, N.F. Fyodorov, K.E. Tsiolkovsky, A.F. Agienko, P.I. Ivanitsky, V.I. Vernadsky, N.K. Roerich, etc. Logical, historical, and comparative methods were used. The evaluation of the offered information contained in works of different thinkers was given from the position of a modern vision of the questions being studied, taking into consideration the level and prospects of the technical development of humanity, and the challenges of the XXI ${ }^{\text {st }}$ century. It is observed that more intensive understanding of the potential of the state as a historical phenomenon took place while understanding cosmic aspects of the state in the history of political thought. Thinkers of different countries started to comprehend more deeply the unity of the world, the cosmic nature of a person and humanity, the foresight and comprehension of the coming cosmic human era and its appropriate political organization. The ideas about the cosmic state played a particular role in the liberation of the individual, and contributed to the development of the conception and forms of economic, political and legal integration, thereby extending the historical horizons of political consciousness.
\end{abstract}

Keywords: Space, state, civilization, mythology, Cynics, Plato, Tsiolkovsky, Roerich, cosmism, biocosmism.

\section{Space and public consciousness}

A person from ancient times tried to find answers to the global world-view questions: "Where are we? How are we, people, connected with space, the stellar sky, and the infinity of other stellar worlds? What will happen to the individual and humanity in the future?

Our planet and the other things which appeared later on it were the result of the long-term evolution of the Universe, the cosmic substance, the complex combination of cosmic influence on it (the intensity of sunlight, the magnitude of air temperature, the different emissions and fields, gravitation levels, collisions and destructions of celestial bodies, the formation and ruin of stars, etc.) The individual couldn't but notice the sky, the sun and the moon, stars, planets, meteors, comets, solar and lunar eclipses. He had to explain such things, comparing them with the Earth, his own world.

As the world gradually disclosed the inner genetic bonds between the parts of the comprehensive whole, it showed its inner, natural unity to some 'wise men', who now and then stated extremely clear and meaningful judgments about the connection between man and space, and about the cosmic fate of humanity. While studying the human and human nature, natural law, the nature of the planet and space seemed to be more closely connected, and interacted with each other. Sometimes it was unconsciously rationally, nevertheless: their inner connection was caught by consciousness, quite often even by intuition, especially in olden times, and it was reflected in assertions and formulae of different levels of accuracy.

From ancient times space was a real living environment for the individual and humanity: it was connected with the individual in different ways. The individual has never been isolated nor been accepted separately from space, neither in real life nor in the public consciousness. Space has never been a 'stranger' for him. Even in early political philosophy we can see elements of cosmic perception of not only natural but social, political and legal aspects of the world organization as well as the nature and the distant prospect of statehood development - the search for the deeper meaning of nature, and the prospects of the evolution of the individual, humanity in general, and the forms of their living.

It seems to be that for the present the cosmic perception of the individual himself and the visual environment as well as political and legal public sector by human individual and public consciousness was an 'anoetic' element of consciousness from old times (i.e. not subject to conscious attention). The research into 'cosmic perception' has only occurred during the past 5-6 years of evolution. Data from that period is more reliable. For the last two centuries and especially in the middle of the $\mathrm{XX}^{\text {th }}$ century the perception of space and the cosmic consciousness of humanity are being developed comprehensively, and have been getting substantiation not only in theory but by means of experiments and in practice. 
Ideas of the unity of the cosmic and earthly orders, the cosmic state in olden times

The ideas of interconnection of the individual, the human society, its leaders, and heads of states with space can be seen in political-legal thoughts at different stages of history. In ancient mythology we find ideas everywhere about a God-like power which has a Heavenly origin. Quite often its synonym was the notion of power, the might of Heaven, and the synonym for Gods was 'celestial beings'. From old times many nations had mythological patrons of the state, legislation, court, justice, law. In public, religiously-political, mythological consciousness, the functioning of the state, its power and martial success, and prosperity of people were connected with the support of the divine might, the hierarchy of Heaven.

In the ancient Sumerian mythological/religious consciousness there were ideas about the united organization of space, about a divine cosmic state with the legislative power, and with the President of the Gods' Council, Anu (Ann, Enn) as a leader. This state united a celestial being, people, animals, and other creatures. In ancient Sumerian mythology the most important thing was the God, Enlil, who was the head of the powerful executive power of the Heavenly state. He could run the elements, and use them to deliver the judgments made by the Gods' Council' ${ }^{1}$.

At the end of the 1950s M. M. Agrest suggested a hypothesis that the mythology of the Ancient Sumerians, and the Bible, and other sacred literature contained the information about the visit to the Earth by extra-terrestrial astronauts who were accepted by the ancient people as the gods who had come from Heaven ${ }^{2}$. Later, the hypothesis was supported by some other researchers into ancient history who tried to find the signs of ancient attendances on Earth by other cosmic civilizations, and they also made attempts to decode different ancient myths in this vein ${ }^{3}$.

\footnotetext{
${ }^{1}$ Udartsev S. F. Pravovoe gosudarstvo: smyslovye grani doktriny (iz istorii phylosophy prava) // Nauchnye trudy “Adilet” (Almaty), № 1 (9), 2001. S. 5- 35 [in Russian]; Udartsev S. F. Istoriya politicheskich i pravovych ucheniy. Drevny Vostok: Akademichesky kurs. - SPb: Izdat. Dom St.-Peter. Gos. Un-ta, Izd-vo yuridicheskogo fakulteta SPbGU, 2007. - 664 s. [in Russian].

${ }^{2}$ Shklovsky I. S. Vselennaya, zhizn, razum. Izd-vo 3-e, dop. i pererab. M.: «Science», 1973. S. 283 - 286 [in Russian].

${ }^{3}$ Deniken E. Nebesnye uchitelya. Translated from German by G. Sachatsky. M: Izd-vo Eksmo, 2005. - 192 s. [in Russian]; Deniken E. Nasledie Bogov. Translated from German by S. V. Golova and A. M. Golova. M.: Izd-vo Eksmo, 2006. - 432 s. [in Russian]; Deniken E. Kamenny vek byl inym, Translated from German by S. V. Golova and A. M. Golova. M.: Izd-vo Eksmo, 2006. - 288 s. [in Russian]; Deniken E. Istoriya oshibochna. Translated from English by I. Kochneva. SPb.; Piter, 2011. - 240 s. [in Russian]; Sytchin Z. Kosmicheskiy kod: Gen-
}

According to ancient Sumerian myths the gods arrived on the Earth from the sky and started transforming it, sharing amongst themselves the duties relating to physical labor and organization work. Later, the conflict occurred between two groups of gods was settled by the god, Anu, who came down to Earth. According to that myth, exactly at the moment they decided to create people and entrusted them to discharge physical labor relating to reforming the planet it was done by some Heavenly beings. Thus, the Heavenly beings started to act only as rulers and organizers. According to the inherited myths and the sacred writings of all religions, all the principles of normal, ancient civil law and the remnants of all early legal thought were transmitted via the Heavenly beings from their God to Man. They were the 'Books of the New Covenant' in ancient Israel, the 'Avesta' in ancient Iran, the 'Laws of Manu' in ancient India, and later the 'Koran', etc. In all of these books, according to legend, the wisest, divine, Heavenly intellect assisted to organize the public life of the individual, to create laws - which were the basis for the future legislation of the state.

Besides, quite often in ancient times Sumerian, Assyrian, Hittite kings, ancient Egyptian Pharaohs, and kings of Sparta, etc., and nowadays the heads of many ancient states and later they together with priests were recognized as a connecting link between the Earth and the Sky, earthly and celestial organizations: mediators between people and Gods, the keepers of prophetic utterances from divine oracles. 'Even the origin of the world order in politically-interpreted myths was considered as a long-term conflict between active and passive powers of space,' - stated I. F. Isaev. - In this conflict the first victory over the inactivity is gained only by means of authority; the second decisive victory is won by means of authority and power. Order vanquishes chaos, and creates space with its steady structure, hierarchy, and the system of status. Thus, the cosmic state includes practically all existing being and things (people, animals, natural phenomena and things) as well as some abstract metaphysical notions such as 'justice', 'righteousness', 'full-circle', etc. All these elements were the compound parts of the united cosmic state, but belonged to different political levels. The criterion for their differentiation was authority. Only those cosmic powers whose authority made people tremble was $=$ were considered as

naya inzheneriya bogov. Translated from English by Yu. Goldberg. M.: Izd-vo Eksmo, 2006. - 320 s. [in Russian]; Sytchin Z. Voiny bogov I ludey. Translated from English by Yu. Goldbeg. M.: Izs-vo Eksmo, 2009. - 432 s. [in Russian]. 


\section{Право и политика 4 (172) $\bullet 2014$}

competent and capable of political influence. Anywhere someone met power and authority, he recognized the Heavenly power within... ${ }^{4}$.

Interesting thoughts about the connection of space, state and law with some elements of order can be found in the writing of the Austrian philosopher of law, René Marcic. Having considered the genealogy of the investigated categories in the book 'From the state of lawfulness to the constitutional state. Law as a measure of power / Thoughts about the democratic, constitutional and social state' he noticed that 'the described genealogy of meaning discloses a basic conclusion to a jurist: space, world, nature, objective reality, reality are the elements of order. The aforementioned conclusion is added to the assertions being basic for the jurist that order is initially considered as a legal order... Former train of thoughts can be generalized in the definition that the Western European spiritual and linguistic history discloses the order which includes considerable points of law, but at the same time ascribes to nature as a general part of the objective reality some points of order. However, to be more precise time adopts nature and the structure of order and considers the world as order.' 5

It is possible to ponder over the combination, alteration, parallel activity and interaction of chaos and order in the Universe, but Marcic fairly notices that from the legal point of view the natural order is inwardly connected with something social, and is the basis of the state and legal order which roots $=$ is rooted in the natural order. Besides, the earthly legal order is an element of the natural order, and is considered as a response while interacting with it.

The Old Testament includes many points disclosing ideas about God's power over the world, the Earth and the Heaven, and the Heavenly kingdom in different ways. Although the notion 'kingdom' and the notion 'statehood' are not authentic, nevertheless the Heavenly kingdom is the absolute and omnipotent power with the perfect structure, and unattainable ideal for the

\footnotetext{
${ }^{4}$ Isaev I. A. Vlast I zakon v kontekste irratsionalnogo. M.: Yurist, 2006. -478 s. [in Russian] p.31-32; Frankfort G., Frankfort G. A., Wilson J., Jacobsen $T$. V predvery philosophy. Duchovnye iskaniya drevnego cheloveka. Per. s ang. T. N. Tolstoy. Otv. Red. i avtor vstup. st. V. V. Ivanov. M.: Nauka, 1984. - 236 s. [in Russian], p.131,162; Udartsev S. F. Politiko-pravovye idei i miphologiya v Mesopotamii, Hettskom tsarstve i Drevnem Irane // Problemy teorii prava i gosudarstva, istorii politiko-pravovoy mysli. Sbornik rabot uchenikov, druzey, kolleg professora O. E. Leist / Otv. Red. N. G. Belyaeva i A. A. Matyuhin. Almaty: AYu-VShP «Adilet», 2005. S. 189-205 and etc. [in Russian].

${ }^{5}$ Marcic Rene. Vom Gesetzesstaat zum Richterstaat. Recht als Maß der Macht / Gedenken über den demokratischen Rechts-und Sozialstaat. Wien: Springer-Verlag, 1957. S. 7.
}

earthly power and the earthly state. Nevertheless, the earthly power and state are considered as a pale image of the Heaven power.

In ancient literature we can find the connection between the life on the Earth and the life in space, and many ancient gods and some characters in ancient literature are considered as heavenly beings who came to the Earth 'out of the blue', or space, or visited Heaven and connected with heavenly beings. Thus, the 'Old Testament' and the ancient Indian 'Mahabharata' contains some specific characters (for instance, Arjuna and Yudhishthira in ' $M a$ habharata'), who travelled from the Earth into Heaven as gods, and even came back out of the blue with new knowledge, new technologies - ('the singing shell'), which was a powerful weapon, being able to 'shake mountains'. When Arjuna, a character in ancient Indian mythology, showed the power of his heavenly weapon to his brother, Heaven sent a heavenly being, and at the second time forbade him from demonstrating the power of the destructive weapon without a reason.

His brother, Yudhishthira, was put to the test before going to Heaven in the 'golden chariot' which was sent down to him, and accomplished it with credit. (He refused to go without the devoted dog following him closely, which later turned out to be the god, Dharma). Having got to Heaven he was again put to the test relating to the observance of justice, and passed it successfully. He preferred to be in the Underworld among good people than to be in Paradise among bad people and enemies. He overcame illusions of vices and virtues, and he knew the true Paradise where he found his relatives and him himself ${ }^{6}$.

Three apocryphal books, Ethiopian, Slavonic, and especially late Jewish ones, contain the story about a biblical character, Enoch, who was sent to Heaven, and who was acquainted with its hierarchical structure and the distribution of the divine heavenly power. They also contain information about myriads of angel camps in Heaven, about disclosures of 'all the sacraments of the Absolute Law' and 'all the mysteries of the world and orders... of God's creations' given to Enoch?

Ideas of the divine heavenly power, of dependence of the earthly orders on the power and jurisdiction of the

\footnotetext{
${ }^{6}$ Yudhidshira // Wikipedia. Svobodnaya entsiklopedia. - http:// ru.wikipedia.org/wiki/\%D0\%AE\%D0\% B4\%D1\%85\%D0\%B8\%D1 \%88\%D1\%82\%D1\%85\%D0\%B8\%D1\%80\%D0\%B0 - 04.07.2012.

${ }^{7}$ Tantlevsky I. R. Kniga Enoha. Arameiskie fragmenty knig enoha iz Kumrana. Evreiskaya kniga Enoha, ili knigs Nebesnyh Dvortsov. Sefer Yetzirah - Kniga Sozidaniya. Prilozhenie: Efiopskaya versiya knig Enoha. Ierusalim: Gesharim: M.: Mosty kultury, 2002. - 376 s. [in Russian], p. 188. See also: p. 189, 193, 197, 221 and etc.
} 
heavenly state, of the organizational unity of the world, of joining Heaven and Earth into one organized system, were seen in some symbols and rituals in the developing earthly state. It became apparent in the ideas of the superhuman power of rulers, their dynasties, their connection with Heaven, and the heavenly rulers, in their contacts and warnings about future disasters (inundations, floods, etc.), in recognition of the rulers of the ancient states as sons of Heaven, the God, and quite of as the Gods. The ideas of the unity of the earthly and heavenly hierarchy was realized in special rituals and religious robes consolidating in the public consciousness the link between rulers and Heaven or gods in different situations and in different periods of their governing (including rituals of rejuvenation, and the revival of power and health).

It has connection with ancient Chinese conceptions such as 'tyan min' and 'ge min'. The first conception of the 'heavenly mandate' was based on the heavenly approval of right to power, governing, and authorization by Heaven as the highest instance of the legitimacy of earthly power. The second conception is based on Heaven's participation in changes of the 'heaven mandate', the depriving of the legitimacy of the power of a certain ruler or dynasty, the right to change them, the excuse for their overthrow, and the right to make a revolution.

In ancient China the most powerful idea of different Chinese schools was the recognition of Heaven's will as the universal power. Lao-tzu considered that all forms of the objective reality are assigned/determined by 'Heaven's will', and taking into account the similarity of the origin of Heaven and Earth he regarded the heavenly predestination of all earthly things due to the natural law and laws of self-organization ${ }^{8}$. Confucius was convinced that the ideal state had to be based on the connection between public administration and law, with morality, ritual and etiquette. The highest moral values - which are practically heaven's guidelines - are accepted as the supremest guidelines for the ideal state. The connections between the heavenly and earthly orders are accepted as the fundamental principles of the world.

In ancient Greek philosophy the fundamental principles were those which had connection with ideas of the cosmic state, as well as ideas of cosmic order and unity of divine (heavenly) and human worlds. In ancient Greek

\footnotetext{
${ }^{8}$ See in detail: Udartsev S. F. Lao-Tse. Drevneyshy predshestvenik idey samoorganizatsii kosmosa, obshestva i cheloveka // Sinergetika obrazovaniya. Mezhvusovsky sbornik (vypusk vtoroi) / Yuzhnoe otdelenie Rossiysloy akademii obrazovaniya; Moskovsky gosudarstvenny pedagogichesky universitet. Moskva; Rostov-na-Donu: Izd-vo Rostovskogo gos. Pedagogicheskogo universiteta, 2004. S. 216 - 254 [in Russian].
}

mythology people associated the appearance of statehood, order and morality with Zeus' activity ('the Inspiring sky'). He was the supreme divine-being, the father of all Gods and people, the head of the Olympic family of Gods?

The answers to the following questions: 'What are people? - [Her.] Mortal Gods. - What are Gods? - [Her.] Mortal people' are ascribed to Heraclitus of Ephesus (544483 B.C. $)^{10}$. Heraclitus established the link between the might and the power of the God with the power over the Universe. Speaking about the highest wisdom he noticed: 'The Wise being [Creature] can be considered as only one thing: Intellect - which can govern the whole Universe. ${ }^{11}$

According to legend, Pythagoras of Samos (570490 B.C.) was the first who called the Universe as 'space' i.e. the order. The ancient Greek wise men believed that 'both Heaven and Earth, both Gods and people, are united by friendship, decency ..., chastity and justice'. Therefore they call 'this visible world' as 'space' (order) but not 'acosmium' (disorder) and dissolution'. ${ }^{12}$ The result was not only political but both moral and legal unity of space permeated by the general highest justice.

Pythagoras developed the ideas of wholesomeness as the basis for establishing justice in the range of God's power over it. All varieties of the earthly power he considered as subordinated powers of God. In his opinion, 'the first powers over the policy are God and the temple; the second one is the power of fathers and the king; the third one is legislative meetings of citizens; the fourth power is the judicial one, the fifth power is that of the officials ${ }^{13}$.

The typical feature of political studies of the Cynic School accepting critically any forms of existence of ancient states was cosmopolitanism. In sources preserved till nowadays=the present day we can find ideas of Antisthenes (about 444/435-370/360 B.C.) about the world mission of the philosopher, and the thoughts of Crates of Thebes

\footnotetext{
${ }^{9}$ Losev A. F. Zhevs // Mifologiya. Bolshoy entsiklopedichesky slovar / Gl. red. E. M. Meletinsky. 4-e izd. M.: Bolshaya Rossiyskaya entsiklopediya,1998. S. 220 - 221 [in Russian], Losev A. F. Prometey // Ibid. S. 451 [in Russian].

${ }^{10}$ Fragmenty rannich grecheskih filosofov. Chast I. Ot epicheskih teokosmogomiy do vozniknoveniya atomistiki. Izadanir podgotovil A. V. Lebedev. M.: Nauka,1989. - 576 s. [in Russian],p.180.

${ }^{11}$ Fragmenty rannich grecheskih filosofov. Chast I. Ot epicheskih teokosmogomiy do vozniknoveniya atomistiki. Izadanir podgotovil A. V. Lebedev. M.: Nauka,1989. - 576 s. [in Russian],p.176.

${ }^{12}$ Fragmenty rannich grecheskih filosofov. Chast I. Ot epicheskih teokosmogomiy do vozniknoveniya atomistiki. Izadanir podgotovil A. V. Lebedev. M.: Nauka,1989. - 576 s. [in Russian],p.147.

${ }^{13}$ Pythagoras. Zolotoy kanon. Figury ezoteriki. M.: Izd-vo Eksmo, 2003. - 448 s. [in Russian],p.307.
} 


\section{Право и политика 4 (172) 2014}

(IVth-IIIrd centuries B.C.) about the fatherland covering 'all lands of the village, any huts which are ready to embrace it $^{14}$. But the brightest cosmopolitan ideas belong to the founder of the ancient Cynics, Diogenes of Sinope (about 412-323 B.C.) who was the follower of Antisthenes. Diogenes of Sinope taught how Diogenes Laertius passed on that the 'only true state' is 'the whole world" ${ }^{15}$. For him the individual was a citizen of the Universe, and his house and state are finally the whole world, but not any city-state or a state uniting several cities. In some other part of his famous book Diogenes Laertius writes: 'To the question: "Where is he from?", Diogenes answered, "I am a citizen of the world ${ }^{16}$." I. M. Nahov writes: 'The Cynic is an anarchist. According to him 'cosmopolitanism' is a thing gained by an inner-free Cynic wise man meaning the possibility to live everywhere, without a definite place of living, ignoring geography, state, class and race barriers, laws, conventions, customs, etc. Cynic wanderers strenuously emphasize their independence, their belonging to no clan. "Look at me," - said Diogenes. - "I do not have a motherland, property, family. Only the Sky and the Earth." But these words include the statement: "I cannot be called a citizen of the world, or all the more of a particular city-state, but I am a part - I am a citizen of the whole nature and the Universe (space) as an embodiment of its highest harmony, justice, reasonableness and order. The true state is in space (Diogenes L. VI, 72), and I am its citizen. ${ }^{17}$

According to the legend 'cosmopolicy', as the world community of wise creatures, was considered by the founder of the Stoic School, Zeno of Citium (about 334/333$262 / 261$ B.C.). It seemed to be described in his first works, as 'The State'. At that time he was under the influence of the Cynics. The idea included the state-legal ideals of Stoicism $^{18}$, and later was accepted by Roman Stoics.

Democritus (about 460-370 B.C.) stated a similar idea, but in another context. He believed that for a wise person and a good soul the whole world was a fatherland, and the wise person could adapt himself to live in any condition and be happy.

\footnotetext{
${ }^{14}$ Nahov I. M. Kinicheskaya literature / Vstupl. A. F. Losev. M.: Glavnaya redaktsiya vostochnoy literatury izd-va «Nauka», 1981. 303 s. [in Russian],p.31.

${ }^{15}$ Diogenes Laetius. O zhizni, ucheniyah I izrecheniyah znamenityh pilosofov. M.: «Mysl», 1979. - 620 s. [in Russian], p.257.

${ }^{16}$ Diogenes Laetius. O zhizni, ucheniyah I izrecheniyah znamenityh pilosofov. M.: «Mysl», 1979. - 620 s. [in Russian], p.254.

${ }^{17}$ Nahov I. M. Kinicheskaya literature / Vstupl. A. F. Losev. M.: Glavnaya redaktsiya vostochnoy literatury izd-va «Nauka», 1981. 303 s. [in Russian], p. 31-32.

${ }^{18}$ Zenon iz Kition - biografiya, fakty iz zhizni, fotografii, spravochnaya informatsiyahttp://www.piplz.ru/page.php?id=422 - 11.06.2012 [in Russian].
}

The most ancient institution of defense that has the 'constitutional' bases of the earthly state, with the support of authority of the heavenly power, is traced to Ancient Sparta. Its implementation is related to the period of government of Lycurgus (circa XIth-Xth centuries B.C.). In Sparta the keeper of the heavenly wisdom - of the unwritten constitution, which was the basis of establishing the state structure and existing order, were the group of the 'CEOs' -that is 'the Ephors'. 'The Ephors' possessed a wide range of supervisory authorities, and could divest the king of his authority - (there were two kings in Sparta). For instance, if they found his activity during a war was incompetent, and causing damage to Sparta. The ideological basis of the power of the Ephors was that they were keepers of the divine bases of the earthly order. They implemented Heaven's authority through heavenly powers.

But the most interesting concept of the protection of rights was described in the works of Plato (about 428/427$348 / 347$ B.C.), the follower of Socrates. By the way, in the suggested accusation against his teacher relating to his alleged disrespect for the gods the accusers referred to Socrates' freethinking about stars.

Plato considered the eternal, divine, cosmic order by its implication, size and universality as a system of ideas, or in some way as a world's program. The ideas about such an order were closely connected with his ideas about the perfect, true state as an ideal model for all prevailing states where the idea about an ideal state became deformed under the influence of a great number of external and internal circumstances. As I. A. Isaev noticed 'the idea of Plato's state contained necessary features and methods which could be used by ambitious builders of the earthly states. It is understood that they will never excel nor perceive it fully, but nevertheless they will have to attend to it. ${ }^{19}$

Thinking about law, Plato admitted that law was not something separate but the projection of divine (cosmic) intellect - a wise facility for the society, relations between a great number of people and their behaviour. If the sophist, Protagoras, believed that a person was a measure of law and legitimate things, so, according to Plato, they were a divine, cosmic intellect. And if it was a person, he was, as it were, a creature who was connected with space by nature. He taught that a legislator should try to embed reasonableness into the state as deeply as possible, and eliminate unreasonableness as quickly as possible. The organisation of the state, with its laws, had to cohere - for the general benefit of the state.

\footnotetext{
${ }^{19}$ Isaev I. A. Ideya poryadka v konservativnoy retrospective.M.: Prospect, 2011. -400 s. [in Russian],p.9.
} 
At the same time the leading role was given to progressive and wise rulers because he considered that wise and just laws had to be respected and protected vigilantly. Plato wrote that 'any business shall be finished in order to be done, got, and set up: although business can be considered as "finished" only if the means found promote to save what has come into the world; otherwise the unity is devoid in some essential parts. ${ }^{20}$ Different states have different aims under different forms and circumstances. Plato noticed that the aims of the state often 'wandered', and some states pursued many objects at the same time ${ }^{21}$. He believed that the state had to value virtues such as courage, reasonableness, discretion and justice above all.

According to Plato the ideal state had to have a special protective 'supreme-state'22 body for the protection of the bases of Law - that is 'cosmic laws...'23. He named such a body as 'Night meeting' ${ }^{24}$, and offered to this 'divine meeting', when it would be created, to 'present a state', ${ }^{25}$-that is, care about security and the justice of its laws. This body would compare the legislation of the earthly state with the cosmic bases of law. One of the woks by Plato was named as 'After the law, or The Nocturnal Council, or The Philosopher'26. I. A. Isaev supposed that Plato 'developed his ideal state as a correlate of outer space...' on the basis of Socrates' idea 'that only special knowledge gives power, and is a preliminary condition of the citizen's participation in the state's governance. ${ }^{27}$.

According to Plato the 'The Nocturnal Council' is utopian for his time, and it is like an ancient philosophical prototype of a constitutional court of the XXth or XXIst centuries. Perhaps, to be more exact,it is like the European Court of Justice ${ }^{28}$ to which not only national institutions of European countries but constitutional courts appeal, on the issues relating to constitutionality (i.e. the necessary validity) of pan-European acts, and the necessity of interpreting them, etc. In addition to that, the supervisory body over

\footnotetext{
${ }^{20}$ Platon. Soch.v. treh tomah. T. 3. Ch. 2. M.: «Mysl», 1972. -678 s. [in Russian], p.466.

${ }^{21}$ Ibid, p.469-470.

22 ibid, p.467.

${ }^{23}$ Ibid, p.476.

${ }^{24}$ Ibid, p. 467.

${ }^{25}$ Ibid, p. 478.

${ }^{26}$ Diogenes Laetius. O zhizni, ucheniyah I izrecheniyah znamenityh pilosofov. M.: «Mysl», 1979. - 620 s. [in Russian], p. 167.

${ }^{27}$ Isaev I. A. Ideya poryadka v konservativnoy retrospective.M.: Prospect, 2011. - 400 s. [in Russian], p. 13.

${ }^{28}$ Marchenko M. N. Sravnitelnoe pravovedenie: uchebnik. 2-e izd., pererab. i dop. M.: Prospect, 2011. - 784 s. [in Russian] , p. 552.
}

the justice system designed by Plato was at a much higher level, insofar as the fundamental cosmic bases of law being the most important principles of law and morality were the criteria for the testing of legislation.

According to Plato the 'Supreme Body' - instituted to protect the laws - shall meet 'early in the morning when every member of the present body is free from any personal and state business. ${ }^{29}$ Plato assumed there was the possibility of having special traveling for studying foreign legislation and the institutes protecting it, "in order to find if there is something suitable to protect laws..." ${ }^{30}$ That is, he realized the necessity of the protection of the bases of law, and he admitted the existence of different forms of protection.

Plato was sure that "no mortal person can be firm in piety if he does not learn ... two points: firstly, that the soul is older than everything in the world because it is given at birth: it is immortal, and rules over all bodies; secondly, as we often said, the intellect that exists in the celestial bodies existing [that is - the king] is the intellect of all things. ${ }^{31}$

According to Plato, a single individual, and all humanity are phenomena in the cosmic sequence connected with the gods, and the beginning. In the dialogue 'Laws' he put forward hypotheses that it is possible that people taken as living beings are ruled by something from without, and are 'wonderful dolls=creatures of the gods', created for some special aim which only gods know. At that point Plato passed ahead of some other modern hypotheses about the origin of life and consciousness, as well as science fiction interpretations of the nature of an individual and his consciousness: he was two and a half thousand years ahead of his time.

In Plato's works such as the dialogues 'Timaeus' or 'Critias' there the first mention about the legendary civilization of Atlantis, which preceded the civilization of mankind, and was a confederative island state. Atlantis is of considerable interest. According to Plato Atlantis having a divine origin suffered from a crisis of society - the collapse of morality, numerous shocks and finally, its destruction as a punishment by the gods because of the loss of connection with moral principles.

In ancient political-legal thought the just structure of the state was connected with Heaven - the Sun. It is no mere chance that during Aristonicus' servile insurrection (IInd century B.C.), the idea about 'the sun state' was popu-

\footnotetext{
${ }^{29}$ Platon. Soch.v. treh tomah. T. 3. Ch. 2. M.: «Mysl», 1972. -678 s. [in Russian], p. 467.

${ }^{30} \mathrm{Ibid}$

${ }^{31}$ Platon. Soch.v. treh tomah. T. 3. Ch. 2. M.: «Mysl», 1972. - 678 s. [in Russian], p. 476.
} 


\section{Право и политика 4 (172) • 2014}

lar. It was borrowed from the novel 'The Island of the Sun' written by the ancient utopist, Iambulos (about the IInd century B.C.). The fragments of the novel were saved in the writings of other thinkers, particularly, in the works of Diodorus Siculus (Ist century B.C.). Later Yambula's ideas had great influence on works of Campanella, when he was writing his famous book 'The City of the Sun' (1602).

In the IInd century Lucian of Samosata (about 120-180 A.D.) while he took a great interest in cynicism, created a fabulous work about space flights (including moon flights and 'Star Wars', in which the representatives of the Polar Star and the Milky Way participated. He also mentioned Capricorn flights, on the planet (island) Lamp. ${ }^{32}$

In ancient Rome, the Stoic, Lucius Annaeus Seneca (4 B.C. - 65) wrote about two states, that is, the earthly one to which people were attached by chance, and the cosmic one. He noticed that different people serve in different states: some people serve in a small one; others serve in big one that is cosmic; the third group of people serve in both states. Roman stoics admitted all people as citizens of the universal state that is cosmopolitan.

Cicero also considered that the individual is a phenomenon of cosmic scale, and he shared the ancient Greek Cynics' and Roman Stoics' ideas about the fact that the individual is 'not an inhabitant of the limited place surrounded of the city walls but the citizen of the whole world, as of the united city... ${ }^{33}$ He considered the right of all living beings as a natural right, and also admitted its universal character.

\section{From the Middle Ages to recent history}

The Fall of the Roman Empire seemed to make Augustine of Hippo (354-430 A.D.) understand temporariness and permanency, instability and the steadiness of differentiation of their principles in the statehood, and in the organization of people. In his famous work 'The City of God' Augustine wrote about a sinful and unstable city, torn by conflicts and wars which appeared to help people to survive, and also about the city which was divine, supreme and eternal as an example of perfection and justice, and to which the righteous men and all kinds of people had to tend. The Church was connected with it: as with the city, which was perfect, fair and morally divine (heavenly). 'Well,' - wrote Augustine of Hippo, - 'if there is no justice the city is like a small

\footnotetext{
${ }^{32}$ Strazhneva Irina. Udivitelnaya zhizn Flammariona M.: Molodaya gvardiya, 1995. S. 161 - 162. [in Russian].

${ }^{33}$ Cicero. O zakone. Kn. II. // Cicero. Dialogi. O gosudarstve. O zakonah. Izd. podgotovili. N. Veselovsky, V.O. Gorenshtein and S. L. Utchenko. M.: Izd-vo «Nauka», 1966. - 224 s. [in Russian], p. 108.
}

gang of robbers, as the gang of robbers is neither more nor less than a state in a miniature. ${ }^{34}$. Neither the unity of people nor the state itself was exposed to critics but the state was vicious, immoral, violent, and brutal. The divine city (state) was admitted to be perfect, as it corresponded to the aims and admonitions of the Church, but it was not realized on the Earth by God's plan. At the same time he made a differentiation between cities not from the point of geography but from the point of view of their spirituality. In this sense, according to Augustine, not only on the Earth but in the cosmic state organizing the exploration of space and the vital functions of the cosmic civilization, it is also possible to single out the human city and the City of God.

The hierarchical correlation of divine, ecclesiastical and temporal power was substantiated by the medieval Christian doctrine of two swords. According to the doctrine, the church gets from God and submits one sword to the state as a symbol of derivation of temporal power from divine, heavenly power, and the second sword plays the role of a mediator between God and temporal rulers. The sword left in the church as a symbol of divine power could always be a basis for blame of unrighteous earthly temporal power and as an evidence of the church's right to strip of power of a temporal monarch in the name of maintenance of God's power.

During the flourishing of medieval European science, the idea about the possibility of a great number of worlds' existences gains general acceptance even among ideologists of the Catholic church. This point was approved by the ecclesiastical regime in 1277 in France. ${ }^{35}$

During the Renaissance not only the idea of the possibility, but also the necessity of the existence of a great number of inhabited worlds started to spread extensively. They were produced by the endlessness of divine power, kindness and the embodiment of all possible things into reality by God. The condemnation and burning at the stake of Giordano Bruno is one of the tragic manifestations of the struggle between the supporters and the opponents of these ideas. The part played by the reactionary Inquisition was to try to prevent the development of science, and the unification of theology and scientific thought.

In history there were ideas about a special mission, 'dharma', a fate, a status of the head of the state, a ruler

\footnotetext{
${ }^{34}$ Augustine of Hippo. O grade Bozhiem. Mn.: Harvest, M.: AST, 2000. - 1296 s. [in Russian],p. 165

${ }^{35}$ Ernan Mak Mallin. Zhizn i intellekt za predelani Zemli: teologiya formuliruet problemy // Mnogo mirov. Novaya Vselennaya, vnezemnaya zhizn i bogoslovskiy podtext / Pod. red. Steven J. Dick; translated from English by V. L. Oleynik. N.: AST; Astrel. 2007. - 224 s. [in Russian], p. 185.
} 
(especially a monarch), about his connection with heavenly power, with space, with the Creator of the Universe, with God. These ideas spread extensively in the Ancient World, in the Middle Ages, and during the Renaissance.

In his treatise 'Monarchia' Dante Alighieri gave the explanation of the oneness of people, their historical purposes and potential development, and he admitted the divine character of the imperial power. Thinking about it he noticed that the potentiality of mankind cannot be disclosed only in one person: it can only be done in a great number of people. ${ }^{36}$ Therefore, there must exist an order securing the realization of the creator's will in it. Mankind consists of parts, but it itself is a part of a more general whole. The order becomes apparent in the relations between parts, and the proportion of the parts to the whole. 'In a broad sense,' - wrote Dante, - 'humanity is like something which consists of parts, and all of which are some part of the whole. In reality it is a whole, consisting of certain kingdoms and peoples ...; it is some part of the Universe, and it is a fact. Just as the subordinate parts of the general notion 'humanity' are in appropriate correspondence with it, and it shall be true that it itself is in compliance with its whole. The parts fit in with 'humanity' by means of the single beginning, as can be easily understood from mentioned above; therefore, 'humanity' fits in with the Universe, or its head (god, or monarch) by means of just the sole beginning, i.e. the sole head. ${ }^{37}$ Hence Dante made conclusions: 'Monarchy is necessary for the world to have its prosperity; ${ }^{38}$ that the human race governed by one ruler 'corresponds most to the idea of God; therefore, it meets most closely the divine intention, i.e. that everything shall be good and perfect...' ${ }^{39}$ Dante also made a conclusion that since the power of the emperor does not depend on other people, including the high priest (eventually it does not mean the rupture between them or of definite relations), it is directly connected with 'the head of the Universe - God'. 'Thus,' Dante wrote, 'it is obvious that the temporal power of the monarch descended to him from the source of the universal power directly, without any other intervention. ${ }^{40}$

During the Middle Ages and the Age of the Enlightenment the ideas of cosmopolitanism, especially that of

\footnotetext{
${ }^{36}$ Dante Alighieri. Monarhiya / Translated from Italian by V.P. Zubov; Commentaries by I. N. Golenishev-Kutuzov. M.: «KANON-press-Ts» - «Kuchkovo pole», 1999. p. 26 - 27 [in Russian].

${ }^{37}$ Ibid, p. 32-33.

${ }^{38}$ Ibid, p. 33.

${ }^{39}$ Ibid, p. 34.

${ }^{40}$ Dante Alighieri. Monarhiya / Translated from Italian by V.P. Zubov; Commentaries by I. N. Golenishev-Kutuzov. M.: «KANON-press-Ts» - «Kuchkovo pole», 1999. p. 138 [in Russian].
}

universal citizenship were being developed and used in a struggle against the feudal division and for the liberation of the individual. The forming of the world market during the existence of capitalism has also stimulated the development of cosmopolitanism ideas. ${ }^{41}$

The development of astronomy in more recent times has led to the spreading and an understanding of the fullysubstantiated hypothesis relating to the possibility of existence and widely spreading in space of the rational life, not only in the XVIIIth and XIXth centuries, but even among atheists and Christian thinkers. 'When the observation of the Universe through a telescope revealed to the onlooker the immense infinity of the world, he started to think that having created infinity God hardly ever intended to populate it with different living beings. ${ }^{42}$ For instance, in his work 'The Century of Wisdom. Investigation of true and artificial theology' (1794) one of the ideologists of the American struggle for independence, Thomas Paine, (1737-1809) wrote about the population of wise creatures from our planet and planets of other stellar systems. He supposed that the thought about the solitary world of people 'in the immense space was substituted by the joyful idea about the unity of worlds getting on well with each other:even its simple developing is for a person's edification. ${ }^{23}$

\section{Ideas about the cosmic state in Russian cosmism at the beginning of the $\mathrm{XX}^{\text {th }}$ century}

For many centuries the ancient ideas about the cosmic nature of the individual and the state have been developed actively due to scientific and technical revolutions, and the scientific substantiation of the practical possibility of space flights.

At the end of the XIXth century and at the beginning of the XXth Nikolai Fyodorovich Fyodorov (1828-1903) developed his ideas. The study of this unique thinker has had a great effect on the cosmic philosophy of K. E. Tsiolkovsky (1857-1935).

N. F. Fyodorov believed that Man, having dissipated all natural resources during his evolution on the Earth, has

\footnotetext{
${ }^{41}$ MarchenkoM.N.. Gosudarstvo I pravo v sisyeme globalnogo miroporyadka (filosofskiy aspekt) // Filosofiya prava. Kurs lektsiy v 2-h tomah. T. 1. Otv. sost. M. N. Marchenko. M.: Prospect, 2011. $-552 \mathrm{~s}$. [in Russian], p. 228.

${ }^{42}$ Ernan Mak Mallin. Zhizn i intellekt za predelani Zemli: teologiya formuliruet problemy // Mnogo mirov. Novaya Vselennaya, vnezemnaya zhizn i bogoslovskiy podtext / Pod. red. Steven J. Dick; translated from English by V. L. Oleynik. N.: AST; Astrel. 2007. - 224 s. [in Russian], p.186.

${ }^{43}$ Payne T. Izbrannye sochineniya / Pod red. M. P. Baskin. M.: Izd-vo AN SSSR, 1959. - 424 s. [in Russian], p.284.
} 


\section{Право и политика 4 (172) 2014}

to start studying space, and reorganizing it. According to Fyodorov the cosmic regulative and transforming activity on humanity will spread further, depending on the extent of space. An individual ' ... born on tiny Earth, a spectator of infinite space, the spectator of worlds of this space, is to become their inhabitant and a ruler ${ }^{34}$. (The italic type of the original has been saved). Fyodorov wrote about the prospects of making make the individual into 'an owner of the Universe. ... Therefore, "blind power" will be governed by intellect. ${ }^{45}$ (The italic type of the original has been saved)

However, he noticed that as we have evolved the state as a legal and economic unity is to be transformed into a closer spiritual organization - into a fraternity of people. Then the state shall 'embody' an organization which 'does not resist God's will'... 'is a connection between people and God' with a renewed religion where the latter is 'identical with knowledge', and connected with the power of people who have comprehended many laws of nature, including those which have brought people closer to becoming immortal, and with the possibility of resurrection. ${ }^{46}$ This future 'supermankind' will possess 'the greatest virtue', as an embodiment of 'the natural duty of wise creatures in the whole, transforming the "blind", unreasonable power of nature occurring spontaneously and capable of killing, into the power governed by intellect' ${ }^{47}$

In the works about cosmic philosophy K. E. Tsiolkovsky stated the hypotheses about the existence of the political organization of cosmic civilizations, the functioning of councils and presidents, representatives of planets, stellar systems, and other cosmic unities on such a scale within which the cosmic civilization can exist.

In the work 'The Will of the Universe' (1928) K. E. Tsiolkovsky wrote: 'We are sure that the mature creatures of the Universe have the means to travel from one planet to another planet, to interfere into the life of the remaining planets, and to support the mature creature as they are. One day the people of the Earth will unite, and they will be all governed by one particular council under the direction of the president of this council.

'It will happen soon. Later, the Solar system will be occupied too. It will be also governed by the particular

${ }^{44}$ Fedorov N.V. Sochineniya / Obshaya redaktsiya: A. V. Gulyga; Vstupit. statiya, primechaniya i sostav. S. G. Semenova. M.: Mysl, 1982. - 711 s. [in Russian], p.528.

${ }^{45}$ Ibid.

${ }^{46}$ Ibid, p. 548-549.

${ }^{47}$ Ibid, p. 557. council with its chairman. It cannot be in another way because intellect demands it.

'Besides, other planets and solar systems will be united. The difference is only in the fact that the most systems will be quickly occupied by mature creatures, or, to be more precise, by the generation which has been prepared, who are ready to govern. The Earth and the Solar system has had a long and painful way of developing. ${ }^{48}$

K. E. Tsiolkovsky believed that the law of space was the establishment of such an order during which all suffering would disappear. He admitted that the 'powerful organization' of wise space creatures having an ability to penetrate into any planet could 'conquer' the Earth too. ${ }^{49}$

In the work 'Unknown wise power' (1928) K. E. Tsiolkovsky came back again to the theme of power organization in cosmic civilizations. He wrote: 'There exists an elective president expressing the will of the people on each perfect planet. Each solar system from billions of millions of people has its own 'high spokesman'. The groups of the Suns are united by their president. Every Milky Way (billions of solar systems) has too. It is possible that the Ethereal Island (the combination of Milky Ways) has such unity too.

'Thus, the power of the wise creatures is united under the chairmen of the planets, the solar systems, the stellar group, the Milky Ways and the Ethereal Islands, etc. We can hardly imagine what a powerful force it is. It is beyond belief that it has no influence on this pitiful earthly life. It is impossible that a mother will not support or save her baby. Therefore, it is impossible to imagine that the Earth can be left to itself. Some independence is given only for getting experience in order to achieve perfection (but not for downfall). ${ }^{50}$

In the article 'Cosmic Philosophy' (1935) K. E. Tsiolkovsky noticed that further thousands and millions of years of development of human civilization 'improved the nature of the individual, and his social organization. Humanity would be as a unity under the direction of its president. He would be the best from amongst all people,both physically and intellectually. However, if the members of the society were highly-qualified, the scientifically-selected one could not be inferior to them. ${ }^{51}$

In Tsiolkovsky's work 'Movers of the Progress' (1928) where people and public figures were classified according

\footnotetext{
${ }^{48}$ Tsiolkovsky K. E. Kosmicheskaya filosofiya. Sbornik. Sost. D. N. Popov. Primechaniya - E. A. Logaevsly, V. V. Kazyutinsky. M.: IDLi, 2001. - 496 s. [in Russian], p.111.

${ }^{49}$ Ibid, p. 112.

${ }^{50}$ Ibid, p. 119-120.

${ }^{51}$ Ibid, p. 461.
} 
to their role and development of humanity the most important people were public figures who 'led humanity to happiness' and united it. ${ }^{52}$ Tsiolkovsky supposed that the social arrangement of wise creatures evolves progressively during evolution in space, and is one of the factors in the successful development of space, and their transforming activities.

On planets and stellar systems he considered that communities would be organized and headed by their leaders-presidents. These organizations would cooperate and form larger ones, etc. The writer wrote: 'We see an infinite number of presidents with different degrees of perfection. Since there are no limits to the number of categories, thus there are no limits for personal development... ${ }^{53}$ It was supposed that the simplest and still not discovered parts are the most stable elements, and the bases for a material and spiritual life. Tsiolkovsky called them 'immortal citizens of space. ${ }^{54}$ According to Tsiolkovsky, with complex and sufficiently large unifications of atoms, their different combinations form cosmic states. In many cases their stability 'depends on the mechanism of union'. 'The state can have such a system which will not only be saved, but it will defeat all other organizations. ${ }^{55}$. 'Tsiolkovsky's anthropocosmic conception, if we consider it without edits, - - writes Kazyutinsky, - 'is a really special intellectual phenomenon. It includes the bright features of a socialphilosophical utopia. Nevertheless, it shall not be forgotten that it was precisely the cosmic philosophy that was the conceptual basis for the drawing up by Tsiolkovsky of specific scientific and technical prognoses of space exploration. The first steps of the cosmic era brilliantly proved the essential part of these prognoses. ${ }^{56}$

A hundred years later the ideas about the cosmic activity of humanity developed by Tsiolkovsky seem to be idealistic and utopian to a curtain extent. However, it is necessary to take into consideration that he often considered things as being a rather distant prospect. The modern reality about the formation of the cosmic era is different:

${ }^{52}$ Tsiolkovsky K.E. Moya pishushayamashinka. Dvigateli progressa. Kalugs. 1928. S. 12 [in Russian]; Ogurtsov A. P. Znaniya I kosmos: gnoseologiya kosmizma // Filosofiya Russkogo kosmizma. Otv. redaktory: A. P. Ogurtsov, L. V. Fesenkova. M.: Fond «Novoe tysyachiletie», 1996. - 376 s. [in Russian].

${ }^{53}$ Tsiolkovsky K. E. Kosmicheskaya filosofiya. Sbornik. Sost. D. N. Popov. Primechaniya - E. A. Logaevsly, V. V. Kazyutinsky. M.: IDLi, 2001. - 496 s. [in Russian], p. 387.

${ }^{54}$ Ibid.

${ }^{55}$ Ibid , p. 389.

${ }^{56}$ Kazyutinsky V. V. Kosmicheskaya folosofiya Tsiolkovskogo // Filosofiya russkogo kosmizma. Otv.redaktory: A. P. Ogurtsov, L. V. Fesenkova. M.: M.: Fond «Novoe tysyachiletie», 1996. 376 s. [in Russian], p. 130-131. it is far from perfection, that is, it is a social organization of humanity, with the super-militarization of cosmic activity, with extremely expensive equipment, projects and programs, and the dangerous ecological consequences of modern materials and technology ${ }^{57}$.

The reflection of the process of alternative comprehension of ideas about future forms of cosmic civilization was the creative work of biocosmists who criticized and made an inspection of the theory of anarchism, and performed one of the tendencies of Russian cosmism at the beginning of XX century and post-classic anarchism.

The biocosmists (A. F. Agienko, P. I. Ivanitsky and etc.) criticized the classic anarchism of P. Zh. Prudon, M. A. Bakunin and P. A. Kropotkin for utopianism because of its initial limitedness and considered it as a theory aimed at creature comforts and standards. The biocosmists admitted that an appropriate thing for the bases of anarchism and maximal freedom to the individual can be only infinite space. When the person is in space and possesses cosmic space, he will be able to implement his utmost rights: the right to move, including traveling in infinite space; the right to live, including the implementation of ideas about immortality, etc. At the beginning of the XXth century according to the biocosmists the idea about the full liberation of the individual and humanity will be able to be carried out if the cosmic civilization exists. Besides, they connected this stage of the evolution of humanity with its refusal from=by the state as a form of organization of human society. Thus, the implementation of anarchism ideals which turned out to be practicable neither in revolution nor in the society of the XVIII ${ }^{\text {th }}$ and $\mathrm{XX}^{\text {th }}$ centuries on the Earth were postponed to the future, and were connected with further cosmic civilizations. Firstly, anarchic ideas about the negation of the state existence were used only for the state of the cosmic civilization proceeding from the premonition of the possibility of its formation. The basis for criticism and negation of the state of the cosmic civilization existed before its real appearance and the beginning of the cosmic era ${ }^{58}$.

\footnotetext{
${ }^{57}$ Krichevsky S. V. Aerokosmicheskaya deyatelnost: metodologicheskie, istoricheskie, sotsioprirodnye aspekty. M.: Izd-vo RAGS, 2007. - 316 s. [in Russian], p.247.

${ }^{58}$ Udartsev S. F. Biokosmism: predposylki vozniknoveniya, kritika I revisiya teorii anarhisma / AN SSSR, Komissiya porazrabotke nauchnogo naslediya Tsiolkovskogo. IF AN SSSR, Gos. muzey kosmonavtiki im. K. E. Tsiolkovskogo // Tr. XXV chteniy, posvash. Razrabotke nauchnogo naslediya I razvitiya idey K. E. Tsiolkovskogo (Kaluga, 11-14.09.1990). Sektsiya: K. E. Tsiolkovsky I filosofskie problemy osvoeniya kosmosa: Kosmonavtika I perspektivy chelovechestva: filos-sotsialniy aspekt. Sb. st. M.: IIET AN SSSR, 1991. S. 233 - 242 [in Russian]; Udartsev S. F. Biokosmism: predchuvstvie kosmicheskoy ery / Mezhdunarodniy god kosmosa [1992] / Avtor statyi I publikatsii // Prostor (A.). 1992. № 4. S. 160 - 166 [in Russian]; Udartsev S. F.
} 


\section{Право и политика 4 (172) • 2014}

However, the experience of the beginning of the cosmic era proves that the state, its functions in the organization of public authorities, its concentration and redistribution of resources lose not only topicality but become much more necessary as civilization develops technically. The activity of the state becomes an important factor in space exploration. In this sense, biocosmism made critical statements relating to classical anarchism, and considered it as utopian. At the same time the ideas of the biocosmists were as a catalyst, and furthered the development of the social and political consciousness of their epoch and broadening of the limits.

The interesting thoughts about the noosphere and the cosmic transforming activity of human activity and its destination during the evolution of the Universe were stated by Pierre Teilhard de Chardin and V. I. Vernadsky. They furthered the comprehension of new horizons of state activity as a political form of organization and regulation of the transforming activity of the humanity in space, as a factor of the evolution of the definite, gradually developing parts of the Universe.

The ideas about cosmic political organization and power structure run through the works of N. K. Roerich. Roerich's writings ${ }^{59}$ expound the cosmic origin of humanity starting from the inhabitants of the Moon and Venus who lived a million years ago. There are legends about the appearance of the first two races with discharged density of bodies, about the history of the evolution of the third and the fourth races on the Earth (Lemurians of 6-9-meters in height, and Atlantes of 3 -5 meters in height, with some information about their social and political organization). It is said about $=$ There are descriptions of the ruler of Venus, about Gods as the first rulers of humanity, about a large Federation of Atlantes under the direction of an emperor, about the Hierarchy of the Great Fraternity of space, and their representatives who were the first rulers of the humanity.

At the present day, E. R. Muldashev's books telling about his expeditions to different places of the planet, particularly to Tibet, also contain the information about races of earthmen living before the known modern history of the humanity, the confirmation of some ancient legends. He stated the hypothesis about storage of human gene pool on the Earth, particularly in Himalayas where the people of previous generation are 'preserved' (in the

Politicheskaya I pravovaya teoriya anarhisma v Rossii: istoriya I sovremennost. Almaty: Kazakhstan; VShP «Adilet», 1994. - 382 s. [in Russian].

${ }^{59}$ Roerich N. K. Sem Velikih Tain Kosmosa. Bishkek: MRIP «Feniks», 1991. - 192 s. [in Russian],p.32-45. form of 'somati' or 'samadhi') in order to restore humanity to life in case of its dearth as a result of a global war, an anthropogenic catastrophe, a cosmic cataclysm, etc. ${ }^{60}$

According to the transpersonal philosophy the universal and fundamental ideas about the world's structure are possibly connected with the conformity of the human consciousness functioning as manifestations, forms of the cosmic intellect, its carrying out of self-knowledge of itself, and its forms of objective reality in the Universe. According to the famous physicist, David Bohm, who was a colleague of A. Einstein, the world is 'an homogenous integrity' with 'hidden, displaced order', which exposes and develops only during the evolution of humanity and its consciousness ${ }^{61}$. .

In modern mystic literature containing something about space there are ideas about the structure of the infinity of levels in our worlds, their correlation and organization. Particularly the following ideas are being developed: the hierarchy of the Absolute (God); existence of the Absolutes of infinity of different levels; cosmic systems as communities of wise creatures proceeding from the hierarchy of God; matrixes of laws controlling all activities, processes and conditions; planets-double developing parallel to the basic planet, a little bit ahead or behind it; 'Unity' - about the wise cooperation of hierarchical systems holding the Earth under control, etc. ${ }^{62}$ The state in future will aim to serve the planet as a whole, with universe laws, and to assist to bring peoples' lives closer the lives of the gods. ${ }^{63}$

Observing the history of ideas about the cosmic state it can be said that these ideas were rarely mentioned in society until the telescope had been invented, astronomy had been developed, and the scientific and technical revolutions of the two last centuries had happened. These ideas belonged more to certain thinkers and scientists who followed and developed them for a number of reasons. Despite the subjective images and the contexts of these ideas they impartially furthered not only the creative perception of the future - thoughts about its forms, and ways of achieving them, but also a critical comprehension of the transient modern political reality - a modern state.

\footnotetext{
${ }^{60}$ Muldashev Ernst Rifgatovich // Wikipedia. Svobodnaya entsiklopedia. - http://ru.wikipedia.org/wiki/Мулдашев,_Эрнст_Рифгатович - 07.05.2012. [in Russian].

${ }^{61}$ Torchinov E. A. Puti filosofii Vostoka i Zapada: poznanie zapredelnogo. SPb.: «Azbuka klassiki», «St. Petersburg Oriental Studies», 2007. - 480 s. [in Russian], p. 397-398.

${ }^{62}$ Seklitova L. A., Strelnikova L. L. Slovar kosmichesloy filosofii. M.: Amrita-Russ, 2004.-208 s. [in Russian], p. 9, 78, 90, 123, 156 and etc.

${ }^{63}$ Platonova T. Yu. O gosudarstve. M.: Beliy ashram, 2000. - 284 s. [in Russian], p. 94, 113 and etc.
} 
During the comprehension of the ideas about the cosmic state religious, mystical, critical, political and naturalscience ways of human thought development intersected. When the cosmic era started these ideas transformed from abstract and utopian concepts into real and practical actualities. Thus the beginnings of the scientific and scientifically prognostic development of these ideas came about.

Analyzing the history of the ideas about the cosmic state as a whole - the organizational unity of the world, the cosmic future of humanity and the forms of life in the cosmic civilization in the history of thought, we can emphasize the following:

- the desire of public consciousness for the individual amongst individuals penetrates into the 'depths' of connection between the state, and the law: the individual, humanity and space: although it is necessary to take into consideration that some particular ideas about the world, its structure were changed during history:

- the existence of ideas about fundamental laws, the organizational unity of Earth and Heaven, about the cosmic nature of the individual and humanity as far as back to ancient times;

- the evolution and interconnection between the mythological and rational comprehension of the place and forms of human objective reality in space;

- the critical comprehension during different epochs of the state and the search for ideal models which broaden out the spatial and temporal limits of this search;

- the moving of ideal notions about the earthly political models, the orders to the Heaven, space, the heaven world;

- some thinkers were ahead of their time, and asserted their ideas which could be implemented and understood only during other epochs, under other conditions;

- the foresight of the cosmic era during the last one and a half or two centuries and especially when it was stimulated by some scientific and technical breakthroughs, and revolutions;

- the hypothetical fame of some ancient knowledge in the ancient world which could be famous due to folklore or early literature, and hardly be found in written form nowadays;

- preparing humanity for the next step in its evolution in accordance with the hypothetical "program of development' of humanity as a developing cosmic civilization which seems to have had a long evolution;

During the gradual historical study of the cosmic aspects of the state in the history of political thought there was an extension of the historical potential of the state. The ideas about the cosmic state, cosmic nature and the prospects of the state played a special role during political struggles of different epochs, in the liberation of the individual, during the transition period from economic, political and legal atomism to the unity and international integration: it broadened the historical horizons of political consciousness.

From the very first days of the existence of the cosmic era these ideas started their transformation from the idea of a utopia - the ideal of the perfect state - to an increase in the scientific and realistic core of it.

\section{Библиография (References):}

1. Udartsev S. F. Pravovoe gosudarstvo: smyslovye grani doktriny (iz istorii phylosophy prava) // Nauchnye trudy “Adilet” (Almaty), № 1 (9), 2001. S. 5 - 35 [in Russian].

2. Udartsev S. F. Istoriya politicheskich i pravovych ucheniy. Drevny Vostok: Akademichesky kurs. - SPb: Izdat. Dom St.-Peter. Gos. Un-ta, Izd-vo yuridicheskogo fakulteta SPbGU, 2007. - 664 s. [in Russian].

3. Shklovsky I. S. Vselennaya, zhizn, razum. Izd-vo 3-e, dop. i pererab. M.: «Science», 1973. S. 283 - 286 [in Russian].

4. Deniken E. Nebesnye uchitelya. Translated from German by G. Sachatsky. M: Izd-vo Eksmo, 2005. - 192 s. [in Russian].

5. Deniken E. Nasledie Bogov. Translated from German by S. V. Golova and A. M. Golova. M.: Izd-vo Eksmo, 2006. -432 s. [in Russian].

6. Deniken E. Kamenny vek byl inym, Translated from German by S. V. Golova and A. M. Golova. M.: Izd-vo Eksmo, 2006. - 288 s. [in Russian].

7. Deniken E. Istoriya oshibochna. Translated from English by I. Kochneva. SPb.; Piter, 2011. - 240 s. [in Russian].

8. Sytchin Z. Kosmicheskiy kod: Gennaya inzheneriya bogov. Translated from English by Yu. Goldberg. M.: Izd-vo Eksmo, 2006. - 320 s. [in Russian].

9. Sytchin Z. Voiny bogov I ludey. Translated from English by Yu. Goldbeg. M.: Izs-vo Eksmo, 2009. 432 s. [in Russian].

10. Isaev I. A. Vlast I zakon v kontekste irratsionalnogo. M.: Yurist, 2006. -478 s. [in Russian].

11. Frankfort G., Frankfort G. A., Wilson J., Jacobsen T. V predvery philosophy. Duchovnye iskaniya drevnego cheloveka. Per. s ang. T. N. Tolstoy. Otv. Red. i avtor vstup. st. V. V. Ivanov. M.: Nauka, 1984. - 236 s. [in Russian].

12. Udartsev S. F. Politiko-pravovye idei i miphologiya v Mesopotamii, Hettskom tsarstve i Drevnem Irane // 


\section{Право и политика 4 (172) • 2014}

Problemy teorii prava i gosudarstva, istorii politikopravovoy mysli. Sbornik rabot uchenikov, druzey, kolleg professora O. E. Leist / Otv. Red. N. G. Belyaeva i A. A. Matyuhin. Almaty: AYu - VShP «Adilet», 2005. S. $189-205$ and etc. [in Russian].

13. Marcic Rene. Vom Gesetzesstaat zum Richterstaat. Recht als Maß der Macht / Gedenken über den demokratischen Rechts-und Sozialstaat. Wien: SpringerVerlag, 1957. S. 7.

14. Yudhidshira// Wikipedia. Svobodnaya entsiklopedia. - http://ru.wikipedia.org/wiki/\%D0\%AE\%D0\% B4\% D1\%85\%D0\%B8\%D1\%88\%D1\%82\%D1\%85\%D0 $\% \mathrm{~B} 8 \% \mathrm{D} 1 \% 80 \% \mathrm{D} 0 \% \mathrm{~B} 0-04.07 .2012$.

15. Tantlevsky I. R. Kniga Enoha. Arameiskie fragmenty knig enoha iz Kumrana. Evreiskaya kniga Enoha, ili knigs Nebesnyh Dvortsov. Sefer Yetzirah - Kniga Sozidaniya. Prilozhenie: Efiopskaya versiya knig Enoha. Ierusalim: Gesharim: M.: Mosty kultury, 2002. - 376 s. [in Russian].

16. Udartsev S. F. Lao-Tse. Drevneyshy predshestvenik idey samoorganizatsii kosmosa, obshestva i cheloveka // Sinergetika obrazovaniya. Mezhvusovsky sbornik (vypusk vtoroi) / Yuzhnoe otdelenie Rossiysloy akademii obrazovaniya; Moskovsky gosudarstvenny pedagogichesky universitet. Moskva; Rostov-na-Donu: Izd-vo Rostovskogo gos. Pedagogicheskogo universiteta, 2004. S. 216 - 254 [in Russian].

17. Losev A. F. Zhevs // Mifologiya. Bolshoy entsiklopedichesky slovar / Gl. red. E. M. Meletinsky. 4-e izd. M.: Bolshaya Rossiyskaya entsiklopediya,1998. S. 220 - 221 [in Russian].

18. Losev A. F. Prometey // Ibid. S. 451 [in Russian].

19. Fragmenty rannich grecheskih filosofov. Chast I. Ot epicheskih teokosmogomiy do vozniknoveniya atomistiki. Izadanir podgotovil A. V. Lebedev. M.: Nauka,1989. - 576 s. [in Russian].

20. Pythagoras. Zolotoy kanon. Figury ezoteriki. M.: Izdvo Eksmo, 2003. - 448 s. [in Russian].

21. Nahov I. M. Kinicheskaya literature / Vstupl. A. F. Losev. M.: Glavnaya redaktsiya vostochnoy literatury izd-va «Nauka», 1981. - 303 s. [in Russian].

22. Diogenes Laetius. O zhizni, ucheniyah I izrecheniyah znamenityh pilosofov. M.: «Mysl», 1979. - 620 s. [in Russian].

23. Zenon iz Kition - biografiya, fakty iz zhizni, fotografii, spravochnaya informatsiyahttp://www.piplz.ru/ page.php?id=422 -11.06 .2012 [in Russian].

24. Isaev I. A. Ideya poryadka $\mathrm{v}$ konservativnoy retrospective.M.: Prospect, 2011. - 400 s. [in Russian].

25. Platon. Soch.v. treh tomah. T. 3. Ch. 2. M.: «Mysl», 1972. -678 s. [in Russian].
26. Marchenko M. N. Sravnitelnoe pravovedenie: uchebnik. 2-e izd., pererab. i dop. M.: Prospect, 2011. 784 s. [in Russian].

27. Strazhneva Irina. Udivitelnaya zhizn Flammariona M.: Molodaya gvardiya, 1995. S. 161 - 162. [in Russian].

28. Cicero. O zakone. Kn. II. // Cicero. Dialogi. O gosudarstve.O zakonah. Izd. podgotovili. N. Veselovsky, V.O. Gorenshtein and S. L. Utchenko. M.: Izd-vo «Nauka», 1966. - 224 s. [in Russian].

29. Augustine of Hippo. O grade Bozhiem. Mn.: Harvest, M.: AST, 2000. - 1296 s. [in Russian].

30. Ernan Mak Mallin. Zhizn i intellekt za predelani Zemli: teologiya formuliruet problemy // Mnogo mirov. Novaya Vselennaya, vnezemnaya zhizn i bogoslovskiy podtext / Pod. red. Steven J. Dick; translated from English by V. L. Oleynik. N.: AST; Astrel. 2007. - 224 s. [in Russian].

31. Dante Alighieri. Monarhiya / Translated from Italian by V.P. Zubov; Commentaries by I. N. GolenishevKutuzov. M.: «KANON-press-Ts» - «Kuchkovo pole», 1999. [in Russian].

32. MarchenkoM.N.. Gosudarstvo I pravo v sisyeme globalnogo miroporyadka (filosofskiy aspekt) // Filosofiya prava. Kurs lektsiy v 2-h tomah. T. 1. Otv. sost. M. N. Marchenko. M.: Prospect, 2011. - 552 s. [in Russian].

33. Payne T. Izbrannye sochineniya / Pod red. M. P. Baskin. M.: Izd-vo AN SSSR, 1959. - 424 s. [in Russian].

34. Fedorov N.V. Sochineniya / Obshaya redaktsiya: A. V. Gulyga; Vstupit. statiya, primechaniya i sostav. S. G. Semenova. M.: Mys1, 1982. - 711 s. [in Russian].

35. Tsiolkovsky K. E. Kosmicheskaya filosofiya. Sbornik. Sost. D. N. Popov. Primechaniya - E. A. Logaevsly, V. V. Kazyutinsky. M.: IDLi, 2001. - 496 s. [in Russian].

36. Tsiolkovsky K.E. Moya pishushayamashinka. Dvigateli progressa. Kalugs. 1928. S. 12 [in Russian].

37. Ogurtsov A. P. Znaniya I kosmos: gnoseologiya kosmizma // Filosofiya Russkogo kosmizma. Otv. redaktory: A. P. Ogurtsov, L. V. Fesenkova. M.: Fond «Novoe tysyachiletie», 1996. - 376 s. [in Russian].

38. Kazyutinsky V. V. Kosmicheskaya folosofiya Tsiolkovskogo // Filosofiya russkogo kosmizma. Otv. redaktory: A. P. Ogurtsov, L. V. Fesenkova. M.: M.: Fond «Novoe tysyachiletie», 1996. - 376 s. [in Russian].

39. Krichevsky S. V. Aerokosmicheskaya deyatelnost: metodologicheskie, istoricheskie, sotsioprirodnye aspekty. M.: Izd-vo RAGS, 2007. - 316 s. [in Russian]. 
DOI: $10.7256 / 1811-9018.2014 .4 .11415$

При цитировании этой статьи сноска на доі обязательна

Правовая и политическая мысль

40. Udartsev S. F. Biokosmism: predposylki vozniknoveniya, kritika I revisiya teorii anarhisma / AN SSSR, Komissiya porazrabotke nauchnogo naslediya Tsiolkovskogo. IF AN SSSR, Gos. muzey kosmonavtiki im. K. E. Tsiolkovskogo // Tr. XXV chteniy, posvash. Razrabotke nauchnogo naslediya I razvitiya idey K. E. Tsiolkovskogo (Kaluga, 1114.09.1990). Sektsiya: K. E. Tsiolkovsky I filosofskie problemy osvoeniya kosmosa: Kosmonavtika I perspektivy chelovechestva: filos-sotsialniy aspekt. Sb. st. M.: IIET AN SSSR, 1991. S. $233-$ 242 [in Russian].

41. Udartsev S. F. Biokosmism: predchuvstvie kosmicheskoy ery / Mezhdunarodniy god kosmosa [1992] / Avtor statyi I publikatsii // Prostor (A.). 1992. № 4. S. 160 - 166 [in Russian].

42. Udartsev S. F. Politicheskaya I pravovaya teoriya anarhisma v Rossii: istoriya I sovremennost. Almaty: Kazakhstan; VShP «Adilet», 1994. - 382 s. [in Russian].

43. Roerich N. K. Sem Velikih Tain Kosmosa. Bishkek: MRIP «Feniks», 1991. - 192 s. [in Russian].
44. Muldashev Ernst Rifgatovich // Wikipedia. Svobodnaya entsiklopedia. - http://ru.wikipedia.org/wiki/ Мулдашев,_Эрнст_Рифгатович - 07.05.2012. [in Russian].

45. Torchinov E. A. Puti filosofii Vostoka i Zapada: poznanie zapredelnogo. SPb.: «Azbuka klassiki», «St. Petersburg Oriental Studies», 2007. - 480 s. [in Russian].

46. Seklitova L. A., Strelnikova L. L. Slovar kosmichesloy filosofii. M.: Amrita-Russ, 2004. - 208 s. [in Russian].

47. Platonova T. Yu. O gosudarstve. M.: Beliy ashram, 2000. - 284 s. [in Russian].

48. Pavroz, A. V. The Welfare State: the Nature of Politics and Fundamental Contradictions // Право и политика. 2011. № 11. C. 21-30.

49. Udartsev, S.F. The idea of the cosmic state in the history of political thought. // Право и политика. 2012. № 8. C. 1386-1399.

50. Ursul, A.D. Globalization of law and global law: conceptual and methodological problems // Pravo i politika. 2012.№ 8. S. 1284-1297. 